\title{
ANALISIS USAHATANI KACANG TANAH DAN JAGUNG DI DESA KANONANG DUA KECAMATAN KAWANGKOAN BARAT
}

\author{
Nanchi Ester Sondakh \\ Ellen Grace Tangkere \\ Olly Esry Harryani Laoh
}

\begin{tabular}{ll}
\hline Naskah diterima melalui Website Jurnal Ilmiah agrisosioekonomi @ unsrat.ac.id & : Senin, 12 Juli 2019 \\
Disetujui diterbitkan & $:$ Kamis, 25 Juli 2019 \\
\hline
\end{tabular}

\begin{abstract}
The purpose of this study was to compare whether peanut farming income was greater than corn farming in Kanonang Dua Village, Kawangkoan Barat District. This research was conducted for 3 months starting from February to April 2019. Determination of farmer samples using a simple random sampling method. Data collected in this study are primary data and secondary data. Primary data was obtained from direct interviews with 15 peanut farmers and 15 corn farmers so that the total respondents were 30 farmers. Secondary data was obtained from the Head of Village office of Kanonang Dua Village, Kawangkoan Barat Sub-district and Statistice office of Minahasa Regency and through the internet, through google searching to obtain scientific journals articles and Bachelor thesis from others university that related to the topic of this research. The results showed that the income received from peanut farming was greater than the income received by corn farming. Peanut farmer Rp.9,309,569 / Ha with a ratio of 2.33 while corn farmers Rp.3,427,500 / Ha with a ratio of $1.77 .^{*}{ }^{*}$ prm*
\end{abstract}

Keywords: income, peanuts, corn, Kanonang Dua Village, Minahasa Regency

\begin{abstract}
ABSTRAK
Tujuan penelitian ini adalah membandingkan apakah pendapatan usahatani kacang tanah lebih besar daripada usahatani jagung di Desa Kanonang Dua Kecamatan Kawangkoan Barat. Penelitian ini dilaksanakan selama 3 bulan mulai dari bulan Februari sampai April 2019. Penentuan sampel petani menggunakan metode pemilihan sampel acak sederhana (simple random sampling method). Data yang dikumpulkan dalam penelitian ini adalah data primer dan data sekunder. Data primer diperoleh dari wawancara langsung kepada 15 petani kacang tanah dan 15 petani jagung sehingga total responden 30 petani. Data sekunder diperoleh dari Kantor Hukum Tua Desa Kanonang Dua Kecamatan Kawangkoan Barat dan BPS Kabupaten Minahasa serta melalui internet, lewat google searching untuk mendapatkan artikel jurnal ilmiah dan skripsi dari universitas lain yang berkaitan dengan topik penelitian ini. Hasil penelitian menunjukkan bahwa pendapatan yang diterima usahatani kacang tanah lebih besar dibandingkan pendapatan yang diterima usahatani jagung. Petani kacang tanah Rp.9.309.569/Ha dengan rasio 2,33 sedangkan petani jagung Rp.3.427.500/Ha dengan rasio $1,77 .^{-* e p r m *}$
\end{abstract}

Kata kunci : pendapatan, kacang tanah, jagung, Desa Kanonang Dua, Kabupaten Minahasa 


\section{PENDAHULUAN}

\section{Latar Belakang}

Sektor pertanian mempunyai peran penting dalam keseluruhan perekonomian nasional di Indonesia, hal ini dibuktikan dengan diletakkannya sektor pertanian sebagai dasar pembangunan yang nantinya dapat menjadi penopang utama sektor-sektor lainnya (Mubyarto, 2001). Sektor pertanian terdiri dari sub sektor tanaman pangan yang meliputi padi, palawija dan hortikultura, serta sub sektor tanaman perkebunan. Dari keempat sub sektor tersebut hortikultura merupakan salah satu bagian dari sektor pertanian yang dapat dijadikan sumber pertumbuhan ekonomi (Nadhwatunnaja, 2008).

Daerah Sulawesi Utara, sektor pertanian berperan penting dalam keseluruhan perekonomian daerah. Hal ini disebabkan karena kondisi alam yang subur menyebabkan sektor pertanian memberikan kontribusi yang besar bagi pembangunan di Sulawesi Utara, dan memegang peranan penting untuk membuka kesempatan kerja dan peluang usaha bagi masyarakat, khususnya didaerah pedesaan.

Di Kabupaten Minahasa Kecamatan Kawangkoan Barat memiliki iklim yang cocok untuk tanaman palawija khususnya kacang tanah dan jagung, tanaman ini banyak yang diusahakan oleh petani karena sudah dilakukan secara turun-temurun.

Tabel 1. Luas Tanam, Luas Panen, dan Produktivitas Kacang Tanah Menurut Desa di Kecamatan Kawangkoan Barat Tahun 2017

\begin{tabular}{lccc}
\hline \multicolumn{1}{c}{ Desa } & $\begin{array}{c}\text { Luas } \\
\text { Tanam } \\
(\mathrm{Ha})\end{array}$ & $\begin{array}{c}\text { Luas } \\
\text { Panen (Ha) }\end{array}$ & $\begin{array}{c}\text { Produktivitas } \\
\text { (Ton/Ha) }\end{array}$ \\
\hline Ranolambot & 40 & 33 & 1,50 \\
Tombasian Atas & 39 & 27 & 1,80 \\
Kanonang Dua & 52 & 48 & 1,80 \\
Kanonang Empat & 50 & 41 & 1,80 \\
Kanonang Lima & 46 & 40 & 1,80 \\
Kanonang Satu & 49 & 39 & 1,80 \\
Tombasian Atas Satu & 24 & 19 & 1,80 \\
Tombasian Bawah & 24 & 16 & 1,50 \\
Kayuuwi Satu & 10 & 7 & 1,50 \\
Kayuuwi & 10 & 8 & 1,50 \\
\hline Jumlah & 344 & 278 & 1,68 \\
\hline Sumber $:$ Diolah dari data primer & 2019 & &
\end{tabular}

Sumber : Diolah dari data primer, 2019

Tabel 1 menunjukkan bahwa yang paling besar luas tanamnya yaitu Desa Kanonang Dua dengan luas tanamnya 52 ha, begitupun dengan luas panen kanonang dua berada di posisi pertama dengan luas panen 48 ha dan menghasilkan produktivitas 1,80 ton/Ha.
Tabel 2. Luas Tanam, Luas Panen, dan Produktivitas Jagung Menurut Desa di Kecamatan Kawangkoan Barat Tahun 2017

\begin{tabular}{lccc}
\hline \multicolumn{1}{c}{ Desa } & Luas Tanam (Ha) & Luas Panen (Ha) & $\begin{array}{c}\text { Produktivitas } \\
(\text { Ton/Ha) }\end{array}$ \\
\hline Ranolambot & 180 & 164 & 3,50 \\
Tombasian Atas & 117 & 117 & 3,50 \\
Kanonang Dua & 103 & 101 & 3,80 \\
Kanonang Empat & 81 & 74 & 3,80 \\
Kanonang Lima & 88 & 84 & 3,80 \\
Kanonang Satu & 104 & 102 & 3,80 \\
Tombasian Atas Satu & 72 & 72 & 3,50 \\
Tombasian Bawah & 52 & 52 & 3,50 \\
Kayuuwi Satu & 100 & 75 & 3,80 \\
Kayuuwi & 69 & 69 & 3,80 \\
\hline Jumlah & 966 & 910 & 3,68 \\
\hline Sumbr & & &
\end{tabular}

Sumber/source : UPT Pertanian Kawangkoan Barat

Tabel 2 menunjukkan bahwa Ranolambot berada di posisi pertama pada luas tanam dan luas panen dengan besar luas tanam 180 ha dan luas panen 164 ha, sedangkan Kanonang Dua memiliki luas panen 103 ha dan luas tanam 101 ha. Pada luas panen dan luas lahan Ranolambot lebih unggul dari Kanonang Dua, namun pada produktivitasnya Kanonang Dua lebih unggul dengan menghasilkan 3,80 ton/ha.

Petani seringkali sulit menentukan jenis usahatani apa yang akan diusahakan, kacang tanah atau jagung. Sehingga diputuskan suatu kajian untuk mengetahui tingkat pendapatan usahatani kacang tanah dan usahatani jagung.

\section{Rumusan Masalah}

Berdasarkan uraian latar belakang yang dikemukakan, maka rumusan masalah dalam penelitian ini adalah apakah pendapatan usahatani kacang tanah lebih menguntungkan daripada usahatani jagung di Desa Kanonang Dua Kecamatan Kawangkoan Barat?

\section{Tujuan Penelitian}

Berdasarkan perumusan masalah, maka yang menjadi tujuan penelitian ini adalah membandingkan apakah pendapatan usahatani kacang tanah lebih menguntungkan daripada usahatani jagung di Desa Kanonang Dua Kecamatan Kawangkoan Barat

\section{Manfaat Penelitian}

Bagi penelitian dapat melatih cara berpikir serta menganalisis data, dan penelitian ini merupakan salah satu syarat untuk memperoleh gelar sarjana di Fakultas Pertanian Universitas Sam Ratulangi Manado. 


\section{METODE PENELITIAN}

\section{Waktu dan Tempat Penelitian}

Penelitian ini dilakukan selama tiga bulan yaitu dari bulan Februari sampai dengan bulan April tahun 2019 mulai dari persiapan sampai penyusunan laporan penelitian. Penelitian ini bertempat di Desa Kanonang Dua, Kecamatan Kawangkoan Barat.

\section{Metode Pengumpulan Data}

Metode yang digunakan dalam penelitian ini adalah metode survey dengan cara mengambil data primer dan sekunder. Data primer diperoleh melalui wawancara langsung menggunakan daftar pertanyaan (quisioner), sedangkan data sekunder diperoleh dari BPS Kabupaten Minahasa, serta instansi yang terkait.

\section{Metode Pengambilan Sampel}

Pengambilan sampel dalam penelitian ini menggunakan metode simple random sampling (sampel acak sederhana), jumlah petani yang dijadikan sampel sebanyak 15 petani kacang tanah dan 15 petani jagung di Desa Kanonang Dua Kecamatan Kawangkoan Barat.

\section{Konsep Pengukuran Variabel}

Adapun variable-variabel yang diukur dalam penelitian ini adalah sebagai berikut:

1. Karakteristik petani:

- Umur (tahun)

- Tingkat pendidikan (SD, SMP, SMA, Perguruan Tinggi)

- Jumlah tanggungan kepala keluarga (orang)

- Jenis tanaman

- Luas lahan yang ditanami (Ha)

- Jenis lahan yang digunakan (milik sendiri, sakap, sewa, kontrak, pinjam/lainnya)

2. Pengeluaran yaitu biaya yang dikeluarkan oleh petani pada proses produksi yaitu:

- Biaya tetap: Penyusutan alat, transportasi.

- Biaya tidak tetap: benih, pupuk, pestisida, tenaga kerja (hok) harian orang kerja.
3. Penerimaan yaitu total jumlah produksi usahatani kacang tanah dan usahatani jagung yang diperoleh per satu kali proses produksi dikali dengan harga (Rp).

4. Pendapatan usahatani kacang tanah dan usahatani jagung yaitu selisih antara total penerimaan dengan total pengeluaran petani dalam 1x produksi (Rp).

\section{Metode Analisis Data}

Analisis data yang digunakan dalam penelitian ini adalah

1. Analisis pendapatan usahatani

a. Biaya produksi (total cost)

$$
\mathrm{TC}=\mathrm{TFC}+\mathrm{TVC}
$$

Dimana $: \mathrm{TC}=$ Total cost (total biaya)

TFC $=$ Total Fixed cost (biaya tetap)

TVC $=$ Total Variable cost

(biaya tidak tetap)

b. Penerimaan (total revenue)

$$
\mathrm{TR}=\mathrm{Q} \times \mathrm{Pq}
$$

Dimana $: \mathrm{TR}=$ Total revenue (penerimaan)

$$
\begin{aligned}
& \mathrm{Q}=\text { Total production } \\
& \quad \text { (jumlah produksi) } \\
& \mathrm{P}=\text { Price (harga jual) }
\end{aligned}
$$

c. Pendapatan petani (income)

$$
\mathrm{I}=\mathrm{TR}-\mathrm{TC}
$$

Dimana $: \mathrm{I}=$ Pendapatan

$\mathrm{TR}=$ Total revenue (total penerimaan)

$\mathrm{TC}=$ Total cost (total biaya)

d. Analisis R/C Ratio

Dalam Harmono dan Andoko (2005), R/C (Revenue Cost Ratio) adalah pembagian antara penerimaan usaha dengan biaya dari usaha tersebut. Analisa ini digunakan untuk melihat perbandingan total penerimaan dengan total biaya usaha. Jika nilai $\mathrm{R} / \mathrm{C}$ ratio di atas satu rupiah yang dikeluarkan akan memperoleh manfaat sehingga penerimaan lebih dari satu rupiah. Secara sistematis $\mathrm{R} / \mathrm{C}$ rasio dapat dirumuskan sebagai berikut :

$$
\mathrm{R} / \mathrm{C} \text { Rasio }=\frac{\text { Total Penerimaan }}{\text { Total Biaya }}
$$

Analisa ini dugunakan untuk melihat keuntungan dan kelayakan dari usahatani. Usahatani tersebut dikatakan menguntungkan jika nilai $\mathrm{R} / \mathrm{C}$ rasio lebih besar dari satu $(\mathrm{R} / \mathrm{C}>1)$. Hal ini menunjukkan bahwa setiap nilai rupiah yang dikeluarkan dalam produksi akan memberikan manfaat sejumlah nilai penerimaan yang diperoleh. 


\section{HASIL DAN PEMBAHASAN}

\section{Deskripsi Daerah Penelitian}

\section{Letak Dan Luas Wilayah}

Desa Kanonang Dua adalah salah satu Desa di Kecamatan Kawangkoan Barat Kabupaten Minahasa. Letak geografis Desa Kanonang Dua berada dilereng/punggung Bukit. Letak astronomi Desa Kanonang Dua adalah antara $01^{\circ}, 18^{\prime} 03^{\prime \prime}$ Lintang Utara dan $124^{\circ}, 77^{\prime} 99^{\prime \prime}$ Bujur Timur. Desa Kanonang Dua berada di ketinggian 804 meter diatas permukaan air laut. Luas wilayah Desa Kanonang Dua adalah $0,713 \mathrm{Km}^{2}$. Adapun batas administrasi Desa Kanonang Dua adalah :

Sebelah Utara : Desa Kanonang Empat Kecamatan Kawangkoan Barat

Sebelah Timur : Desa Pinabetengan

Kecamatan Tompaso

Sebelah Barat : Desa Tombasian Atas

\section{Penduduk}

Kecamatan Kawangkoan Barat.

Jumlah penduduk di Desa Kanonang Dua adalah 708 jiwa pada tahun 2015, 712 jiwa pada tahun 2016, 815 jiwa pada tahun 2017 dan 847 jiwa pada tahun 2018, terbagi atas 422 jiwa laki-laki dan 425 jiwa perempuan 403 jumlah 847.

\section{Karakteristik Responden}

Petani yang menjadi responden dalam penelitian ini adalah petani yang mengusahakan tanaman kacang tanah dan jagung. Petani responden di daerah penelitian ini berada pada usia 41-50 tahun dengan tingkat pendidikan SMP/sederajat, luas lahan rata-rata 0,2-0,5 hektar serta jumlah tanggungan petani rata-rata adalah 2-3 orang.

\section{Umur Petani}

Tabel 3 menunjukkan bahwa sebagian besar petani responden jagung tergolong pada kelompok umur 41-50 tahun dengan persentase $40 \%$ dan sebagian besar responden kacang tanah tergolong pada kelompok umur $<40$ tahun dengan persentase $40 \%$.

\begin{tabular}{|c|c|c|c|c|c|}
\hline \multicolumn{2}{|c|}{ Umur (Tahun) } & \multicolumn{2}{|c|}{$\begin{array}{c}\text { Jumlah Responden } \\
\text { (Orang) }\end{array}$} & \multicolumn{2}{|c|}{ Persentase $(\%)$} \\
\hline Jagung & $\begin{array}{c}\text { Kacang } \\
\text { Tanah }\end{array}$ & Jagung & $\begin{array}{c}\text { Kacang } \\
\text { Tanah }\end{array}$ & Jagung & $\begin{array}{c}\text { Kacang } \\
\text { Tanah }\end{array}$ \\
\hline$<40$ & $<40$ & 4 & 6 & 27 & 40 \\
\hline $41-50$ & $41-50$ & 6 & 5 & 40 & 33 \\
\hline $51-60$ & $51-60$ & 3 & 3 & 20 & 20 \\
\hline$>61$ & $>61$ & 2 & 1 & 13 & 7 \\
\hline Total & & 15 & 15 & 100 & 100 \\
\hline
\end{tabular}

Sumber : Diolah dari data primer, 2019

\section{Pendidikan}

Tabel 4 menunjukkan bahwa sebagian besar petani responden jagung tergolong pada tingkat SMA dengan jumlah 6 orang dengan persentase $40 \%$ dan sebagian besar responden kacang tanah tergolong pada tingkat pendidikan SD dengan jumlah 7 orang dengan persentase $43 \%$.

Tabel 4. Jumlah Responden Petani Jagung dan Kacang Tanah Menurut Tingkat Pendidikan

\begin{tabular}{cccccc}
\hline \multicolumn{2}{c}{ Tingkat Pendidikan } & $\begin{array}{c}\text { Jumlah Responden } \\
\text { (Orang) }\end{array}$ & \multicolumn{2}{c}{ Persentase $(\%)$} \\
\hline Jagung & $\begin{array}{c}\text { Kacang } \\
\text { Tanah }\end{array}$ & Jagung & $\begin{array}{c}\text { Kacang } \\
\text { Tanah }\end{array}$ & Jagung & $\begin{array}{c}\text { Kacang } \\
\text { tanah }\end{array}$ \\
\hline SD & SD & 4 & 7 & 27 & 43 \\
SMP & SMP & 5 & 2 & 33 & 14 \\
SMA & SMA & 6 & 6 & 40 & 43 \\
\hline Total & & 15 & 15 & 100 & 100 \\
\hline
\end{tabular}

Sumber : Diolah dari data primer, 2019

\section{Luas Lahan}

Tabel 5 menunjukkan bahwa sebagian besar petani responden jagung memiliki luas lahan 0,2-0,5 ha dengan persentase $73 \%$ dan sebagian besar responden kacang tanah memiliki luas lahan ditanami $0,2-0,5$ ha dengan persentase $93 \%$.

Tabel 5. Jumlah Responden Petani Jagung dan Kacang Tanah Menurut Luas Lahan Yang Ditanami

\begin{tabular}{cccccc}
\hline \multicolumn{2}{c}{ Luas Lahan (Ha) } & $\begin{array}{c}\text { Jumlah Responden } \\
\text { (Orang) }\end{array}$ & \multicolumn{2}{c}{ Persentase $(\%)$} \\
\hline Jagung & $\begin{array}{c}\text { Kacang } \\
\text { Tanah }\end{array}$ & Jagung & $\begin{array}{c}\text { Kacang } \\
\text { Tanah }\end{array}$ & Jagung & $\begin{array}{c}\text { Kacang } \\
\text { Tanah }\end{array}$ \\
\hline $0,2-0,5$ & $0,2-0,5$ & 11 & 14 & 73 & 93 \\
0,7 & 0,8 & 2 & 1 & 13 & 7 \\
1 & 0 & 2 & 0 & 13 & 0 \\
\hline Total & & 15 & 15 & 100 & 100 \\
\hline
\end{tabular}

Sumber : Diolah dari data primer, 2019

\section{Jumlah Tanggungan Keluarga}

Tabel 6 menunjukkan bahwa sebagian besar jumlah tanggungan keluarga petani jagung adalah 3 dengan persentase $47 \%$ dan sebagian besar kacang tanah jumlah tanggungan keluarga 3 dengan persentase $40 \%$.

Tabel 6. Jumlah Responden Petani Jagung dan Kacang Tanah Menurut Tanggungan Keluarga

\begin{tabular}{|c|c|c|c|c|c|}
\hline \multicolumn{2}{|c|}{ Jumlah Tanggungan } & \multicolumn{2}{|c|}{$\begin{array}{c}\text { Jumlah Responden } \\
\text { (Orang) }\end{array}$} & \multicolumn{2}{|c|}{ Persentase $(\%)$} \\
\hline Jagung & $\begin{array}{l}\text { Kacang } \\
\text { Tanah }\end{array}$ & Jagung & $\begin{array}{l}\text { Kacang } \\
\text { Tanah }\end{array}$ & Jagung & $\begin{array}{c}\text { Kacang } \\
\text { Tanah }\end{array}$ \\
\hline 1 & 1 & 3 & 2 & 20 & 13 \\
\hline 2 & 2 & 3 & 3 & 20 & 20 \\
\hline 3 & 3 & 7 & 6 & 47 & 40 \\
\hline 4 & 4 & 2 & 3 & 13 & 20 \\
\hline 0 & 6 & 0 & 1 & 0 & 7 \\
\hline Total & & 15 & 15 & 100 & 100 \\
\hline
\end{tabular}

Sumber : Diolah dari data primer, 2019 


\section{Status Kepemilikan Lahan}

Tabel 7 menunjukkan bahwa sebagian besar menurut status kepemilikan lahan tergolong pada pinjam lahan dengan persentase 53\% untuk petani jagung $47 \%$ untuk petani kacang tanah.

\begin{tabular}{|c|c|c|c|c|c|}
\hline \multicolumn{2}{|c|}{ Status Kepemilikan Lahan } & \multicolumn{2}{|c|}{$\begin{array}{l}\text { Jumlah Responden } \\
\text { (Orang) }\end{array}$} & \multicolumn{2}{|c|}{ Persentase (\%) } \\
\hline Jagung & Kacang Tanah & Jagung & $\begin{array}{l}\text { Kacang } \\
\text { Tanah }\end{array}$ & Jagung & $\begin{array}{c}\text { Kacang } \\
\text { Tanah }\end{array}$ \\
\hline Sewa & Sewa & 4 & 5 & 27 & 33 \\
\hline Pinjam & Pinjam & 8 & 7 & 53 & 47 \\
\hline Hak Milik & Hak Milik & 3 & 1 & 20 & 7 \\
\hline - & Bagi Hasil & 0 & 2 & 0 & 13 \\
\hline Total & & 15 & 15 & 100 & 100 \\
\hline
\end{tabular}

\section{Biaya Total}

Total biaya adalah keseluruhan biaya yang dikeluarkan petani sampel di desa kanonang dua dalam mengelola usahatani kacang tanah dan jagung. Total biaya adalah penjumlahan antara biaya tetap dan biaya variabel.

Tabel 8. Biaya Sarana Produksi pada Usahatani Kacang Tanah dan Jagung

\begin{tabular}{lrrrr}
\hline \multirow{2}{*}{ Uraian } & \multicolumn{2}{c}{ Jagung } & \multicolumn{2}{c}{ Kacang Tanah } \\
\cline { 2 - 5 } & \multicolumn{1}{c}{ Petani } & \multicolumn{1}{c}{ Ha } & Petani & \multicolumn{1}{c}{ Ha } \\
\hline Benih & 29.333 & 58.667 & 683.333 & 1.464 .286 \\
Pupuk Urea & 218.500 & 437.000 & - & - \\
Pupuk SP36 & 212.666 & 425.333 & 32.000 & 68.571 \\
Pupuk Phonska & 132.000 & 264.000 & 16.000 & 34.286 \\
Pestisida & - & - & 217.000 & 465.000 \\
Fungisida & - & - & 343.200 & 735.429 \\
\hline Total & 592.500 & 1.185 .000 & 1.291 .533 & 2.767 .571 \\
\hline Sumber : Diolah Dari Data Primer, 2019 & &
\end{tabular}

Tabel 8 menunjukkan bahwa untuk penggunaan Benih pada Usahatani Jagung petani hanya menggunakan benihnya sendiri sehingga tidak mengeluarkan biaya, namun biaya benih pada usahatani jagung dihitung sebesar Rp.58.667/Ha. sedangkan usahatani kacang tanah petani mengeluarkan biaya benih Rp.1.464.286/Ha.

Tabel 9. Biaya Penyusutan Alat Usahatani Kacang Tanah

\begin{tabular}{ccccc}
\multicolumn{2}{c}{ dan Jagung } & \multicolumn{2}{c}{ Kacang Tanah } \\
Jagung & \multicolumn{2}{c}{ Biaya $(\mathrm{Rp})$} \\
\hline \multirow{2}{*}{ Uraian } & \multicolumn{2}{c}{ Biaya $(\mathrm{Rp})$} & $\mathrm{Ha}$ \\
\cline { 2 - 5 } & Petani & Ha & Petani & Ha \\
\hline Cangkul & 28.750 & 57.500 & 28.750 & 61.607 \\
\hline Sumber : Diolah dari data primer, 2019 & &
\end{tabular}

Tabel 9 menunjukkan bahwa pada biaya penyusutan usahatani jagung dan usahatani kacang tanah untuk rata-rata petani sama sebesar Rp.28.750 namun pada usahatani jagung dan kacang tanah perhektarnya berbeda jumlah besaran biayanya.

\begin{tabular}{lrrrr}
\multicolumn{5}{c}{ Tabel 10. Biaya Tenaga Kerja Usahatani Kacang Tanah dan Jagung } \\
\hline \multirow{2}{*}{ Uraian } & \multicolumn{2}{c}{ Jagung Biaya } & \multicolumn{2}{c}{ Kacang Tanah Biaya } \\
\cline { 2 - 5 } & \multicolumn{1}{c}{ Petani } & \multicolumn{1}{c}{ Ha } & \multicolumn{1}{c}{ Petani } & \multicolumn{1}{c}{ Ha } \\
\hline Bajak & 239.333 & 586.666 & 373.333 & 800.000 \\
P.Bedeng & - & - & 480.000 & 1.028 .571 \\
P.Lubang & - & - & 186.667 & 400.000 \\
Penanaman & 186.667 & 373.333 & 148.800 & 318.857 \\
Tambun & - & - & 186.667 & 400.000 \\
Pemupukan & 160.000 & 320.000 & 13.333 & 28.571 \\
Penyiangan 1 & 313.333 & 626.667 & 633.333 & 1.357 .143 \\
Penyiangan 2 & - & - & 193.333 & 414.286 \\
Panen & 357.400 & 714.800 & 2.076 .667 & 4.450 .000 \\
Rontok & 246.867 & 493.733 & - & - \\
\hline Total & 1.557.600 & 3.115 .200 & 4.292 .133 & 9.197 .429 \\
\hline Sumber : Diolah Dari Data Primer, 2019
\end{tabular}

Tabel 10 menunjukkan bahwa total biaya tenaga kerja yang digunakan pada usahatani jagung adalah sebesar Rp.3.115.200/Ha dan pada usahatani kacang tanah sebesar Rp.9.197.429/Ha.

Tabel 11. Biaya Tetap Usahatani Kacang Tanah dan Jagung

\begin{tabular}{lrrrr}
\hline \multirow{2}{*}{ Uraian } & \multicolumn{2}{c}{ Jagung } & \multicolumn{1}{c}{ Kacang Tanah } \\
\cline { 2 - 5 } & Petani & \multicolumn{1}{c}{ Ha } & \multicolumn{1}{c}{ Petani } & \multicolumn{1}{c}{ Ha } \\
\hline Transportasi & 43.333 & 86.667 & 207.667 & 445.000 \\
Penyusutan Alat & 28.750 & 57.500 & 28.750 & 61.607 \\
\hline Total & 72.083 & 144.167 & 236.417 & 506.607 \\
\hline
\end{tabular}

Sumber : Diolah dari data primer, 2019

Tabel 11 menunjukkan bahwa total biaya tetap pada usahatani jagung sebesar Rp.144.167/Ha lebih kecil dari total biaya tetap pada usahatani kacang tanah sebesar Rp.506.607/Ha.

Tabel 12. Biaya Variabel Usahatani Kacang Tanah dan Jagung

\begin{tabular}{lrrrr}
\hline \multirow{2}{*}{ Uraian } & \multicolumn{2}{c}{ Jagung } & \multicolumn{2}{c}{ Kacang Tanah } \\
\cline { 2 - 5 } & Petani & Ha & Petani & Ha \\
\hline Pembelian Saprodi & 592.500 & 1.185 .000 & 1.291 .533 & 2.767 .571 \\
Biaya Tenaga Kerja & 1.557 .600 & 3.115 .200 & 4.292 .133 & 9.197 .429 \\
\hline Total & 2.150 .100 & 4.300 .200 & 5.583 .667 & 11.965 .000 \\
\hline Sumber : Diolah Dari Data Primer, 2019 & & &
\end{tabular}

Tabel 12 menunjukkan bahwa biaya terbesar yang dikeluarkan dalam usahatani jagung dan kacang tanah adalah biaya tenaga kerja. Rata-rata total biaya pada usahatani kacang tanah adalah Rp.11.965.000/Ha lebih besar daripada usahatani jagung Rp.4.300.200/Ha.

\begin{tabular}{|c|c|c|c|c|}
\hline \multirow{2}{*}{ Uraian } & \multicolumn{2}{|c|}{ Jagung } & \multicolumn{2}{|c|}{ Kacang Tanah } \\
\hline & Petani & $\mathrm{Ha}$ & Petani & $\mathrm{Ha}$ \\
\hline Biaya Tetap & 72.083 & 144.167 & 236.417 & 506.607 \\
\hline $\begin{array}{l}\text { Biaya } \\
\text { Variabel }\end{array}$ & 2.150 .100 & 4.300 .200 & 5.583 .667 & 11.965 .000 \\
\hline Total & 2.222 .183 & 4.444 .367 & 5.820 .084 & 12.471 .607 \\
\hline
\end{tabular}

Tabel 13 menunjukkan bahwa total biaya produksi pada usahatani jagung Rp.4.444.367/ Ha dan pada usahatani kacang tanah Rp.12.471.607/Ha. 
Tabel 14. Pendapatan Usahatani Kacang Tanah dan Jagung

\begin{tabular}{lcccr}
\hline \multirow{2}{*}{ Uraian } & \multicolumn{2}{c}{ Jagung } & \multicolumn{2}{c}{ Kacang Tanah } \\
\cline { 2 - 5 } & Petani & $\mathrm{Ha}$ & Petani & $\mathrm{Ha}$ \\
\hline Total Penerimaan & 3.935 .933 & 7.871 .867 & 10.164 .549 & 21.781 .176 \\
(TR) & & & & \\
Total Biaya (TC) & 2.222 .183 & 4.444 .367 & 5.820 .083 & 12.471 .607 \\
Pendapatan & 1.713 .750 & 3.427 .500 & 4.344 .466 & 9.309 .569 \\
\hline Sumber: Diolah Dari Data Primer 2019 & &
\end{tabular}

Sumber : Diolah Dari Data Primer, 2019

Tabel 14 menunjukkan bahwa usahatani kacang tanah memiliki spendapatan sebesar Rp.9.309.569/Ha lebih besar daripada pendapatan usahatani jagung yang memiliki pendapatan sebesar Rp.3.427.500/Ha.

\begin{tabular}{lcccc}
\multicolumn{2}{c}{ Tabel 15. Efisiensi Total Usahatani Kacang Tanah dan Jagung } \\
\hline \multicolumn{2}{c}{ Uraian } & Petani & $\mathrm{Ha}$ & \multicolumn{2}{c}{ Kacang Tanah } \\
& $\mathrm{Ha}$ & Petani & $\mathrm{Ha}$ \\
\hline Total Biaya & 2.222 .183 & 4.444 .367 & 5.820 .083 & 12.471 .607 \\
Total & 3.935 .933 & 7.871 .867 & 10.164 .549 & 21.781 .176 \\
$\begin{array}{l}\text { Penerimaan } \\
\text { Pendapatan }\end{array}$ & 1.713 .750 & 3.427 .500 & 4.344 .466 & 9.309 .569 \\
R/C & 1,77 & & 2,33 & \\
\hline
\end{tabular}

Tabel 15 menunjukkan bahwa R/C Ratio pada usahatani jagung besarnya 1,77 sedangkan R/C Ratio pada usahatani kacang tanah 2,33. Nilai R/C Ratio kedua usahatani lebih dari 1 yang menunjukkan bahwa kedua usahatani efisien dengan nilai R/C Ratio pada usahatani jagung lebih tinggi daripada usahatani kacang tanah.

\section{KESIMPULAN DAN SARAN}

\section{Kesimpulan}

Dari hasil penelitian ini kesimpulan yang dapat diambil antara lain :

1. Usahatani kacang tanah memiliki pendapatan sebesar Rp.9.309.569/Ha yang lebih tinggi dibandingkan dengan usahatani jagung Rp.3.427.500/Ha. Hal ini karena biaya tenaga kerja dalam keluarga pada usahatani jagung lebih besar dibandingkan dengan biaya tenaga kerja dalam keluarga pada usahatani kacang. Dapat dilihat bahwa dari pendapatan yang lebih menguntungkan usahatani kacang tanah dibandingkan usahatani jagung.

2. Usahatani kacang tanah $(2,33)$ lebih efisien daripada usahatani jagung $(1,77)$.
3. Biaya total yang digunakan petani kacang tanah dalam 1x produksi Rp.12.471.607 petani jagung Rp.4.444.367 1x produksi, hal ini jika petani yang mengusahakan tanaman jagung $3 \mathrm{x}$ produksi disamakan dengan biaya total usahatani kacang tanah maka penerimaannya akan berubah.

\section{Saran}

Dari hasil penelitian ini, disarankan petani di Desa Kanonang Dua sebaiknya membudidayakan usahatani kacang tanah. Karena pembudidayaan usahatani kacang tanah memerlukan biaya yang besar tetapi pendapatannya juga besar dibandingkan usahatani jagung.

\section{DAFTAR PUSTAKA}

Mubyarto. 2001. Pengantar Ekonomi Pertanian. LP3ES Jakarta.

Nadhwatunnaja, N. 2008. Analisis Pendapatan Usahatani Dan FaktorFaktor Yang Mempengaruhi Produksi Paprika Hidroponik di Desa Langu Kecamatan Cisarua. Skripsi. Fakultas Pertanian Bogor. (Akses tanggal 08 April 2019 jam 22:30). 